\title{
Population trends of Finnish Lepidoptera during 1961-1996
}

\author{
Kauri Mikkola
}

Mikkola. K. 1997: Population trends of Finnish Lepidoptera during 19611996. - Entomol. Fennica 8: 121-143.

Based on a query and on a literature review, the population trends of Finnish Lepidoptera since Kaisila's (1962) thorough overview are analysed. Changes in the belt of three coastal biogeographical provinces $(V-E K)$ show significant correlations with those in three inland provinces $(S t-E S)$. Furthermore, positive trends in these belts are reflected as new provincial finds north of them. The spatial synchrony is supposedly caused by spatially correlated climatic conditions. This is supported by evidence of synchronous trends in species grouped according to their overwintering stages (Marttila 1991, Bruun 1992). The increased migration rate, indicated by the new provincial finds, is probably a consequence of high population densities, and does not explain the synchrony itself. Kaisila's division into expansive and fluctuant species is considered to be a historical rather than a biological characterization. During the 19th century, the reporting of new lepidopteran species was delayed by about 50 years if they were night-active vs. day-active. The low numbers of observers and slow development of collecting methods have caused further analytical uncertainties. Some of Kaisila's expansive species may actually have been inhabitants of Finland for long periods of time. At present, drainage of peatlands and overgrowth of meadows are the most adverse environmental changes causing a decline of lepidopterans, particularly of the butterflies. Increase of bushiness and reeds appear to have positively affected many geometrid and noctuid species. The high incidence of new provincial finds and of species new to the country in the 1990 s as well as positive trends in lateautumn and early-spring species supposedly reflect the ongoing climatic change. The Finnish lepidopteran fauna is undergoing a dynamic phase: around 30 recent invaders and 40 older expansive species are spreading, while fewer are retreating; the declining species are mainly habitat specialists while the expansive ones are generalists, mainly feeding on bushes and trees. Fewer expansions are evident among micro- than macrolepidopterans.

Kauri Mikkola, Finnish Museum of Natural History, P.O. Box 17, FIN-00014 University of Helsinki, Finland

Received 10 January 1997, accepted 29 May 1997 


\section{Introduction}

\subsection{Historical aspects and the present article}

Our knowledge of the faunal history of Finnish Lepidoptera is strongly limited by the Turku Fire of 1827 . The library and the collections of the University of Turku (Academia Aboensis) were totally devastated. A small collection of mainly microlepidoptera (Coll. Caloander) was saved from the flames, but nothing of the main collection.

Kaisila (1962) gave a sad account of the disastrous consequences of the fire for Finnish lepidopterology. The results of an 80-year tradition were entirely destroyed. The national collection had been the main tool for identifying butterflies and moths; after the fire no such materials or literature were available for comparison, and most manuscripts had been destroyed. It required 20 30 years before serious lepidopterological research could again be conducted.

The Turku Fire still causes problems, since it did not only interrupt the research being conducted at the time, but also resulted in the disappearance of all previous material. To trace the 18 th century lepidopteran fauna of Finland, we now have only a few Finnish specimens in the collections of Linnaeus and Clerck, and we have the insect catalogues from Oulu by Julin (1791-1800) and the catalogue of Finnish sphingids and bombycoids by Sahlberg (1819), but very little material concerning faunal changes.

Kaisila (1962) produced a monumental work in analysing the expansions and immigrations of Lepidoptera into Finland during 1869-1960. Of the neighbouring areas, he included the Leningrad Oblast (Ingermanland) and Russian Karelia (Olonets), as well as all three Baltic countries. He treated the southern and southeastern species found in Finland after Tengström's (1869) list, and added some migrant and expansive species already reported by Tengström. Unfortunately, he left the southwestern species, many of them published in a supplement by Valle (1946), to be treated by a colleague; later Kaisila (1968) published a brief account of them and other recent new species.

The main idea of Kaisila (1962) was apparently that by comparing the list of Tengström (1869) with the recent situation, he could sepa- rate the basic, local species pool; the new species found after Tengström would mainly be expansive and migrant species.

The present article treats the 36 years since Kaisila's study period. The main task is to follow up on the occurrence of the species treated by him, to determine whether it remains possible to divide them into expansive and fluctuant species and to examine the expansions with respect to environmental changes and global climate change. Other species were added from the observer lists and from recent faunistic literature; in a separate section, the species found as new to the country during 1961-1996 are treated. In the original query, some microlepidopteran species were included, but, since the data were much poorer than those of macrolepidopterans, they were abandoned. The micros are only briefly treated based on discussions with several specialists.

\subsection{What is an expansion?}

Kaisila (1962) classified his species as migrants, fluctuants and expansive species, but he never defined the latter terms. An orthodox definition for expansion might be a postglacial return movement, however, many southern species probably lived in Finland during postglacial, climatically advantageous times, particularly in the Litorina period. What we easily believe to be the first or, postglacial return may in many cases be part of more-or-less regular north-south oscillations. Kaisila (1962) used the term "fluctuant" for the extreme end of an apparently continuous spectrum, for those species that may disappear from the country or from wide areas and return.

At present, the species Limenitis populi and Agrotis segetum (D. \& S.) mainly occur in southeastern Finland and along the southern coast, respectively. Both species show some positive population trends, such that they could easily be referred to as expansive. During the advantageous summers of the late 1930s, however, both species

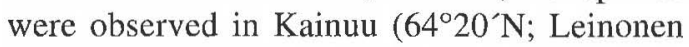
$1993)$, and the former in 1798 at Oulu $\left(65^{\circ} \mathrm{N}\right.$; Kaisila 1959) as well as in 1961 at Kuusamo $\left(66^{\circ} \mathrm{N}\right)$. Both species are in fact at a regressive phase. Thus, short-term observations may give an erroneous idea of the character of the species. 
The variation in wavelength of the fluctuations is a largely unknown parameter, particularly in the long-wave end of it. Warnecke (1961) considered that if a species remains in its newly invaded area for 50 years, with stable or increasing population density, a true expansion (Arealerweiterung) has occurred. Heinicke (1980) examined a 120-year period and decided that if a species has no longer been observed throughout a 50 -year period, it can be considered as disappeared. In the Finnish Red Data Book (Rassi et al. 1986), only those species are treated as disappeared in which the disappearance has occurred after 1850 and where no encounters have been noted after 1960. Some examples of the "wavelength" are given in Section 3.3 .

To be able to discriminate between fluctuation and expansion, I have attempted to consider a considerably longer period: the criterion for a true expansion should be that the species has probably not inhabited the study area (here: Finland) during the most recent 250 years. For historical reasons we cannot have data from more remote periods. As shown in the Introduction, many cases remain obscure within this period, although it may be possible to use some indirect indications.

The differing numbers of observers and variation of methods cause further difficulties in attempts to compare different periods. Kaisila (1962) noted that inland distributions are often unclear, due to the scarcity of observers. With respect to single species, he also wrote many notes on the effects of the revolutionary method introduced during the early 1950 s to Finland: nightcollecting with mercury-vapour and blended lamps. Unfortunately, he attempted to perform total analysis neither of this effect nor of an earlier one, on the introduction of sugaring during the 2 nd half of the 19 th century to catch noctuids.

\subsection{Old Swedish notes on migrant, expansive and fluctuant species}

Some information on the long-term behaviour of species in Northern Europe can be gained from the oldest Swedish observations available, which were actually not treated by Kaisila (1962). The following migrants are reported on the first Swedish list of Lepidoptera by Linnaeus (1739), com- prising 87 species (interpretation of identities: Ander 1944): Pieris brassicae (Linnaeus), P. rapae (Linnaeus), Nymphalis polychloros (Linnaeus), Inachis io (Linnaeus), Vanessa atalanta (Linnaeus), V. cardui (Linnaeus) and Autographa gamma (Linnaeus). In comparison to this relatively exhaustive treatment of migrants, Linnaeus mentions few species today considered expansive or fluctuant: Aporia crataegi (Linnaeus), Issoria lathonia, Maniola jurtina, Tyria jacobaeae and Noctua pronuba.

In his Fauna Suecica, Linnaeus $(1746,1761)$ added two migrants, Colias hyale (Linnaeus) and Macroglossum stellatarum (Linnaeus), to the Swedish list, while of the expansive and fluctuant species he noted Stauropus fagi, Cucullia verbasci (Linnaeus), C. absinthii (Linnaeus) and Ourapteryx sambucaria. In Dalman's 1816 list of Swedish Lepidoptera, the migrant sphingids Acherontia atropos and Agrius convolvuli (Linnaeus) are present but the former was probably found already in the Linnaean time, although later than 1761. Of the expansive and fluctuant species, Lopinga achine was reported from Sweden during the 1820 s by Billberg and Callimorpha dominula (Linnaeus) and Amphipyra perflua in 1838-1840 by Zetterstedt (Ander 1944). The migrant noctuid Schinia scutosa (D. \& S.) was found during the mid-1800s, while the migrant sphingids, Hyles euphorbiae (Linnaeus), H. lineata (Fabricius) and Daphnis nerii (Linnaeus), were reported from Sweden until 1886 (Ander 1944), i.e. within Kaisila's study period.

The late 18th/early 19th century collections in Uppsala, Sweden, of Gyllenhal and Thunberg, include some specimens of interest from the standpoint of the present article: Cleorodes lichenarius (Hufnagel) 4 exx., Alcis jubatus 1 ㅇ, Autographa buraetica (Staudinger) 2 exx. [thus, the expansive character of this species suggested by Kerppola and Mikkola (1987) does not hold], Amphipyra berbera Rungs 2 exx. and Xanthia aurago (D. \& S.). Two very old specimens of Rhyparia purpurata are not necessarily Swedish in origin. Early specimens exist of two species described and named many years later, Spaelotis clandestina and Xestia sincera (Herrich-Schäffer), which in the present study showed local increasing trends (for the former, see Table 5, but note the new knowledge of its collecting; the value of the latter was +3 ). 
Linnaeus (1758) described Phalaeana celsia from Uppsala, honoring his teacher, Professor O. Celsius (see Linnaeus 1746). But how could Staurophora celsia occur then in Uppsala, when it expanded vigorously into Finland 200 years later, after the mid-1930s? It clearly arrived via the Åland Islands, i.e. from Sweden. Either of two possibilities may account for the discrepancy: (1) the old Swedish species really managed to cross the $\AA$ land Sea only in the 1930 s, or (2) it was also present in 18th century Finland as a well-known Linnaean species but later vanished. Such events may well occur: Linnaeus (1758) described Trichosea ludifica (Linnaeus) most probably from Sweden; it was also observed in Sweden during the early 1800 s and for the last time in 1856 (Ander 1945). In Finland it has been known as a stationary but scarce species since the first find in Southern Ostrobothnia during the mid-1800s.

Nothing suggests that the migrations of the 18 th century would have differed from the recent migrations. In contrast, Linnaeus detected migrating species roughly in the expected order. Even the late appearance of Agrius convolvuli in Sweden may be expected, since the main host plant, Convolvulus arvensis, was not as widely spread as at later times (S. Vuokko pers. comm.). In Finland A. convolvuli was found for the first time only in 1905, but from the Baltic countries it was reported already in 1791, and from the St. Petersburg area in 1849. In comparison to the relatively complete list of migrants, few observations are available from the wide spectrum of recent expansive and fluctuant species, suggesting that a

Table 1. Mean year of the 1st appearance of some species treated by Kaisila (1962) in the Baltic area, Ingermanland and Finiand combined.

1. Five migratory butterflies $+A$. gamma $1804 \pm 23$ years $\mathrm{N}=18$

2. Six non-migratory butterflies

$1820 \pm 26$ years $N=12$

3. Three migratory sphingids

4. Eleven (night-active) noctuids

5. Eight geometrids

$1835 \pm 38$ years $\mathrm{N}=9$

$1849 \pm 18$ years $\mathrm{N}=33$

$1853 \pm 19$ years $\mathrm{N}=24$ considerable number of these species probably are new to the Nordic countries.

\subsection{What do the years of appearance in the Baltic area tell us?}

Kaisila (1962) carefully gives the year of first find and/or publication of each species in the Baltic area, the present Leningrad area (his Ingermanland), Russian Karelia (Olonets) and Finland (he used the prewar area; I use the present one). For various groups of Lepidoptera, the first years from the Baltic area, Ingermanland and Finland were collected and their means and standard deviations were counted (Table 1; the data from Olonets are too sporadic). The groups of noctuids and geometrids were chosen according to the year of occurrence in Finland: those species observed here latest in 1885 were included.

The probabilities of various lepidopterans becoming observed have thus been uneven. This is clearly revealed despite the often different timing of the first observations in various geographic areas; roughly half the species have been observed about 30 years later in Finland than in the other areas, resulting in relatively large standard deviations. As expected, daytime habits and large or colourful appearance (easier determination) have in the past affected the years of first observation. The normal noctuids and geometrids were observed on average about 50 years later than the daytime migrants (ANOVA, $\mathrm{F}=55.9, \mathrm{P}<0.001$ ). All 3 sphingids are rare, explaining why they appeared relatively late.

The most interesting detail in the above note refers to the early and expected appearance of migrants in Sweden. In Group 4, the exclusively nocturnal migrant Agrotis ipsilon (Hufnagel) ( $\overline{\mathrm{X}}$ $=1845 \pm 4$ years; $\mathrm{N}=3$ ) does not differ from the others, while Nomophila noctuella (D. \& S.) was observed still later $(\overline{\mathrm{X}}=1867 \pm 19$ years; $N=3)$. These two species are undoubtedly migrants for ever.

If it is considered that Agrotis ipsilon has shown the same behaviour throughout historical times, it forms an indicator of the probability that a normal night-active noctuid would become observed. In other words, A. ipsilon was present at the time when day-active migrants were observed but due to its nocturnal habits it was only observed 
about 40 years later. It may then be interpreted that the 10 other noctuids or most of them, synchronic with A. ipsilon, have also not changed their behaviour. At least Diarsia brunnea, Ammoconia caecimacula, Tholera decimalis, Th. cespitis, Gortyna flavago, Calamia tridens and Herminia grisealis should be considered as species that have occurred in southern Finland for a long time, and the same might be true for such species as Noctua pronuba, Catocala adultera (Ménétriés) and Lamprotes c-aureum (Knoch). Of course, their northern border may have fluctuated considerably.

Kaisila (1962: diagr. 2) himself noted that in the 2 nd half of the 19th century, the noctuids dominated the statistics of species new to the country. This undoubtedly occurred due to use of the new collecting methods, sugaring and collecting from honeydew. It appears that many species which had lived a cryptic life in the country were only then discovered. The very few pre-Tengström collectors using more or less casual methods had not detected them. Progression of the finds from southeast to northeast or from the coasts to the inland may in many cases have described the history of collecting and not expansions of the respective species.

Kaisila (1962) chose to treat 158 macrolepidopterous species, mainly found in Finland after Tengström's (1869) checklist. Of these, only 25 have not been observed in neighbouring countries before 1869 . Thus, the main body of his species have not performed any large-scale expansions. Even among the mentioned 25 species, only a few have first been observed in neighbouring areas during the 1900s: Macdunnoughia confusa, Apamea ophiogramma (Esper) and Xestia sexstrigata, as well as some reed species: Archanara sparganii, A. dissoluta and Senta flammea (Curtis). Several other late newcomers are long-range migrants or irruptive rarities, e.g. Prodotis stolida, Pseudohadena immunda (Eversmann), Apamea zollikoferi (Freyer), Euxoa ochrogaster (Guenée), or local rarities, e.g. Chersotis andereggii (Boisduval) and Eugraphe sigma (D. \& S.). Two species were observed before 1869 only in Finland: Catarhoe rubidata and Pachetra sagittigera (Hufnagel).

With respect to collecting methods, the period 1961-1996 is relatively uniform, although the use of automatic light (Karvonen et al. 1979) and bait traps has steeply increased during the period. In
1964, more than 100 moth lamps were used every night in Finland (Mikkola \& Salmensuu 1965), but few of these were traps. The change might be less significant from the mid-1970s to the present; the number of light traps and lamps used every night is certainly several hundred, while the number of bait traps might be even larger. A feature concomitant with the large number of traps has been that a number of them are used throughout the season along the southern coastline or in the outer archipelagoes. The consequence has been that migrants and irruptive species have been more effectively observed than in earlier decades (Karvonen et al. 1979).

\subsection{Climatic and environmental changes in Finland}

Expansions and retreats of species are apparently affected by three groups of factors:

1. Variations in climate.

2. Changes in the environments, and

3. Intra- and interspecific factors.

Kaisila (1962) emphasized climatic factors and explained the expansions by the so-called ikosaionic (20th century) amelioration. The climatically most favourable periods and most expansions occurred during the 1910 s and 1930 s, but many expansions also occurred during the early 1950 s (but note the effect of the introduction of mercury-vapour and blended lamps).

In the northern latitudes, global warming (IPCC 1996) is a factor that very probably promotes expansions. Instability increases, however, with the warming; e.g. winter periods without snow, long and wet autumn seasons and extended cool and wet periods in the summer are disadvantageous for most Lepidoptera.

Mikkola (1987: fig. 1) analysed the factors threatening insects, other animals and plants presented by Rassi et al. (1986). He showed that, with the exception of bodies of waters, the lepidopterans and plants are threatened by similar factors:

1. The overgrowth of meadows by scrub and forest,

2-3. Species composition of trees/forestry and building activity, and

4-5. Drainage of peatlands and collecting. 
Changes in agriculture thus gravely threaten butterflies and moths, the most important single action being the cessation of forest grazing by cows, horses and sheep; in 1938, $46 \%$ of the forests were still being grazed. Overgrowth of dry meadows has been detrimental for many butterfly species, and deep-draining is another factor making the environments less diverse. For some species, however, the changes may have been positive. Without cattle, overgrowth of scrub, saplings and reeds occurs; this may be referred to as "Bush-Finland".

A decrease in the proportion of old forests may particularly affect the Xestia moths in northern Finland. Only $1.6 \%$ of all forests are more than 140 years old in southem Finland but $19.3 \%$ in northern Finland (Sevola 1996). In forestry, it is peatland draining which has caused the most widespread decline in the Finnish lepidopteran fauna. Until 1992, $74.9 \%$ of peatlands in the south and $38.3 \%$ in the north had been ditched. In the south, many peatland butterflies have disappeared over wide areas, as has also been noted in the query (Table 5B).

By intra-specific I particularly denote acclimatization, slow genetic adaptation to the local, mostly suboptimal climatic conditions. Theoretically, if the climate would remain stable, most species of Lepidoptera would slowly spread northward. Other intra reasons causing population changes include predators, parasitoids and microbes.

\section{Material and methods}

The main aim here is to revisit Kaisila's (1962) species pool, examine what his expansive species and fluctuants have done during the period 1961-1995(-1996, scattered notes from 1997) and determine how this corresponds with his results of 1869-1960; however, the migrants and irruptive species are in general not treated. Geometrids of the genera Apocheima, Colotois, Erannis and Agriopis are included; at least the autumn fliers of these often undertake migratory flights, apparently with expansive results. On the other hand, the well-known migrant Inachis io was excluded, but has remained in Finland since 1972. By virtue of treating Kaisila's species, data on other faunal events during the period 1961-1996 were collected.

A questionnaire was sent to members of the Finnish Lepidopterological Society with a list of 104 expansive or fluctuant species treated by Kaisila (1962), asking the occurrence of these species during the period 1961-1995 (additional data collected for 1996) in each collecting locality; information on other newcomers/declining species was also asked. The following symbols were used, preferably with years: + (species increased $),=($ stable $),-($ declined $), 0$ (not encountered) and ? (not known). Answers were received from 32 localities from the following biogeographical provinces (Fig. 1): V2, U6, EK 5, St 2, EH 10, ES 4, EP 1, PK 1 and $K n \mathrm{l}$. In the treatment, the 3 southernmost provinces, $V$-EK (13 localities), were combined to form the coast and the next 3,St-ES (16 localities), to form the inland. From more northern provinces, only newcomer finds were examined.

Kaisila (1962: fig. 5) chose from his material 58 of the most important expansive species [of these, 2 microlepidopterans (see Introduction) and Catocala nupta (Linnaeus) as partial migrant and Eupithecia pernotata Guenée as a local subspecies were omitted] and 14 fluctuants (his fig. 6). This species pool is the main subject for the present study.

The results for each species from the coastal and inland provinces were treated with the formula (for the symbols, see above):

$$
[(2 \times+)+(0.5 \times=)]-[(1 \times 0)+(2 \times-)]
$$

Thus, increases and declines have been empasized, and the significance of stability is less than that of zero-values. Relatively few question marks occurred and were omitted; the suggestions were accepted as such. The results denote by $+/$ - the tendency toward increases/declines; the larger the value the more unanimity in the material.

Species not treated by Kaisila (1962) but which increased or decreased according to the query or to the recent literature (see next paragraph) are presented in Table 5. Those species receiving, after deletion of $+/$ - pairs, at least five marks in the same direction (+ or - ) are included. By chance, 24 species are present on both lists.

The following published sources were examined: 10 local faunas (Ahola et al. 1983, von Bonsdorff 1985, Hublin \& Savolainen 1985, Suomalainen 1987, Järventausta et al. 1988, Martikainen \& Seuranen 1988, Kontiokari 1989 , Bruun 1992, Leinonen 1993, Kangas 1994), circulars of the Finnish Lepidopterological Society (1961-1975) and (since 1976) the journal Baptria (yearly reports by S. Repo or Repo \& J. Kullberg), and (until 1986) the journal Notulae Entomologicae as well as other relevant literature from the period 1961-1996 (smaller scientific reports are not cited separately). Yearly reports from Sweden, Denmark and Estonia were also studied (see Table 7). The declining, endangered and protected species treated by Rassi et al. (1986, 1992) in the Finnish Red Data Books are not treated here, except for those species included in the query and except for a comparison between increases and decreases (Section 4.3.).

\section{Results}

\subsection{Species of Kaisila (1962) during the pe- riod 1961-1995}

Kaisila's groups of expansive and fluctuant species were strongly heterogeneous, but the results 

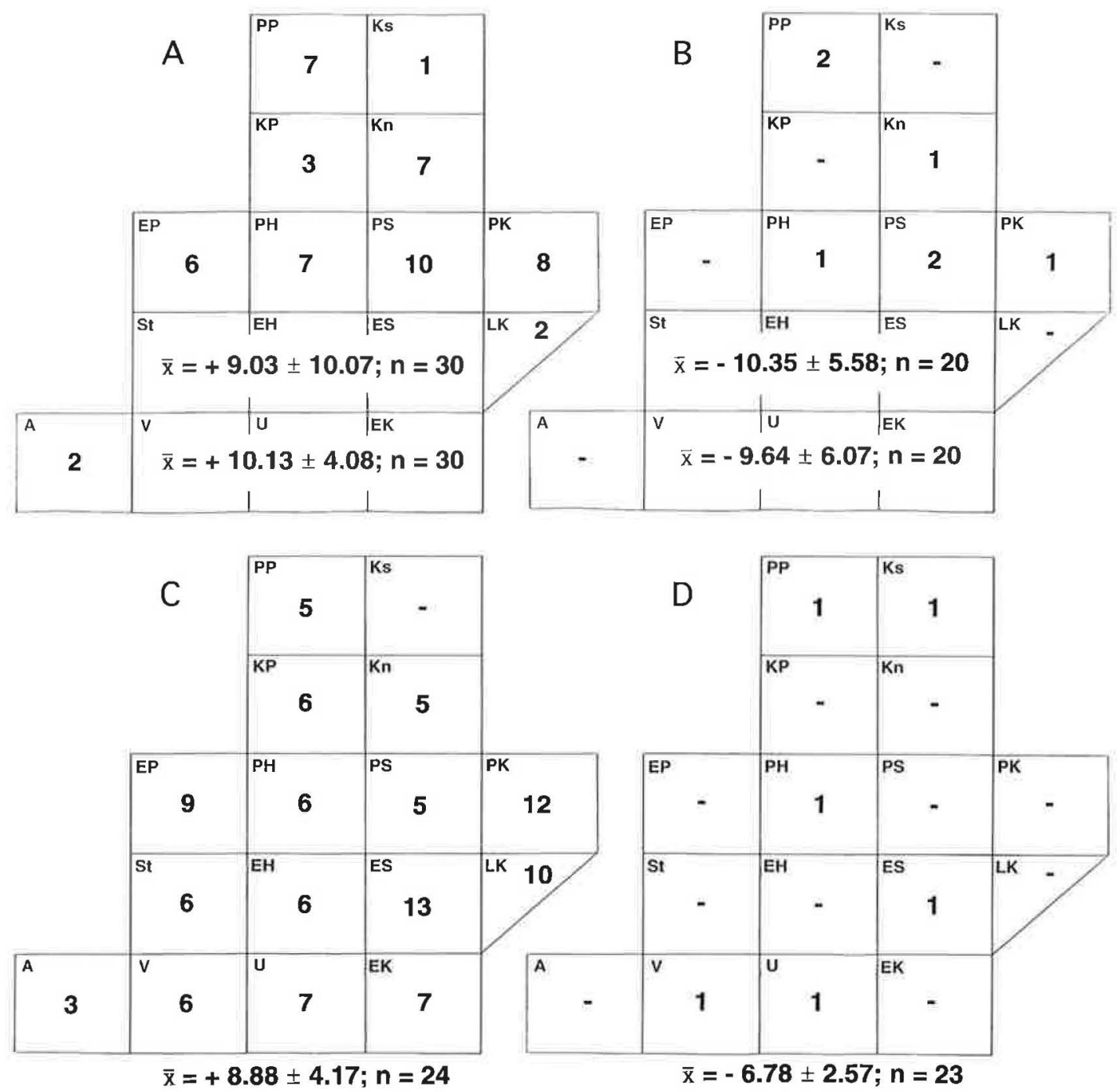

Fig. 1. A schematic presentation of the Finnish biogeographical provinces (Lapland omitted) with data from Tables 2-5 inserted. The means with standard deviations are indexes of increase/decrease (+ or - ) from the query; the numbers in the squares denote numbers of new provincial finds during the period 1961-1996. A-B: Kaisila's (1962) species pool, with the 30 most increased species in A and the 20 most decreased species in B. The values of $V$-EK and St-ES as well as the numbers of provincial finds are independent of each other; for statistical values of the material, see the text. C-D: Corresponding values from recent increases and decreases; statistical values not counted because the provincial finds have partly affected the increase and decrease values.

allow some inferences. The mean of the expansive species from the coast is +4.3 and from the inland +2.1 (from 13 and 16 localities, respectively). Thus, the coastal localities showed mean values of about two +-marks and the inland localities of one mark (the formula doubles the result). The explanation for the difference is probably trivial: several species are present which do not occur regularly in the inland localities, resulting in more unencountered species and, thus, in lower totals.

A similar tendency is seen in the fluctuants: coastal +1.4 and inland -0.07 . As expected, more expansions seem to occur among the expansive species (Table 2: positive values in $30 / 53$ species) 
Table 2. Increase/decrease values from the period 1961-1995 of 54 expansive species of Kaisila (1962: fig. 5). The 2nd and 3rd columns give the values from the coast ( $V$-EK) and from the inland (St-ES); in the 4th column new provincial finds with years are listed. The nomenclature is from Varis et al. 1995. ( ) = later additions, not included in the statistics.

\begin{tabular}{|c|c|c|c|}
\hline & $V-E K$ & St-ES & New provincial finds \\
\hline Allophyes oxyacanthae (L.) & +19.5 & +24 & EH-61, ES-69, LK-89, PH-96, PS-96, PK-92, KP-62 \\
\hline Deileptenia ribeata (Clerck) & +16.5 & -4 & St-63, EP-95, PK-68 \\
\hline Gymnoscelis rufifasciata (Hw.) & +15.5 & -3 & $\mathrm{PH}-96, \mathrm{PS}-64, \mathrm{Kn}-75$ \\
\hline Blepharita satura (D. \& S.) & +14.5 & +17 & PK-92 \\
\hline Hypomecis roboraria (D. \& S.) & +12 & +1.5 & St-81 \\
\hline Lomographa bimaculata (F.) & +11.5 & +21.5 & St-61, EP-85, PH-93, PS-74, PK-61 \\
\hline Polia nebulosa (Hfn.) & +11.5 & +6 & PH-90, PS-75 \\
\hline Xestia sexstrigata (Hw.) & +9.5 & +19.5 & ES-61, EP-84, PH-92, PS-74, PK-91, KP-65, Kn-92, PPe-93 \\
\hline Odontosia sieversi (Mén.) & +9.5 & +19 & $E P-70, K n-67, P P e-69, P P p-83$ \\
\hline Herminia tarsipennalis Tr. & +8.5 & +10 & PS-74 \\
\hline Idaea dimidiata (Hfn.) & +8.5 & +2 & $P S-66, K n-75, P P p-83$ \\
\hline Spilosoma luteum (Hfn.) & +8 & -5 & - \\
\hline Diarsia brunnea (D. \& S.) & +7.5 & +13 & - \\
\hline Idaea biselata (Hfn.) & +7 & +9.5 & $E P-96$ \\
\hline Lomographa temerata (D. \& S.) & +7 & +12 & $K n-92$ \\
\hline Celaena leucostigma $(\mathrm{Hb})$. & +7 & -1 & PPe-68 \\
\hline Catarhoe rubidata (D. \& S.) & +6.5 & -3 & A-76, PS-73, PK-75 \\
\hline Eilema complanum (L.) & +6 & +3.5 & $E P-85$ \\
\hline Colobochyla salicalis (D. \& S.) & +6 & +5 & St-67, PH-91 \\
\hline Schrankia costaestrigalis (St.) & +5.5 & +6.5 & V-61, EK-62, ES-63, PH-95 \\
\hline Ammoconia caecimacula (D. \& S.) & +5.5 & -7 & - \\
\hline Mesoligia furuncula (D. \& S.) & +5 & +8 & - \\
\hline Cepphis advenaria $(\mathrm{Hb})$. & +4.5 & +0.5 & $A-86, S t-89$ \\
\hline Arenostola semicana (Esp.) & +4.5 & -4.5 & $V-65, E S-84$ \\
\hline Laothoe amurensis (Stgr.) & +4 & +16 & KP-89 \\
\hline Herminia grisealis (D. \& S.) & +4 & +3.5 & - \\
\hline Hypomecis punctinalis (Sco.) & +2.5 & -9.5 & - \\
\hline Axylia putris (L.) & +2 & -5 & - \\
\hline Abraxas sylvatus (Sco.) & +0.5 & +2.5 & (St-73) \\
\hline Coenonympha glycerion (Br.) & +0.5 & -2 & - \\
\hline Eupithecia linariata (D. \& S.) & -0.5 & -5 & $E P-78, P P e-71$ \\
\hline Plagodis dolabraria (L.) & -0.5 & -4 & $E S-72, L K-73$ \\
\hline Tholera decimalis (Poda) & -1 & +3.5 & - \\
\hline Stauropus fagi (L.) & -1.5 & -4 & $P S-75$ \\
\hline Larentia clavaria (Hw.) & -2 & +2 & EP-75, (KP-74), Kn-84, PPe-95, PPp-82 \\
\hline Trisateles emortualis (D. \& S.) & -2.5 & -10.5 & $E S-80$ \\
\hline Gortyna flavago (D. \& S.) & -2.5 & +1 & $P S-64$ \\
\hline Melanchra persicariae (L.) & -2.5 & -19 & $P S-71$ \\
\hline Aplocera praeformata (Hb.) & -3.5 & +14 & $E P-68, \mathrm{Kn}-90$ \\
\hline Archanara sparganii (Esp.) & -3.5 & -1 & PS-64 \\
\hline Eupithecia sinuosaria Ev. & -5 & -6.5 & - \\
\hline Tholera cespitis (D. \& S.) & -5 & +5 & - \\
\hline Orthosia gracilis (D. \& S.) & -6 & -6 & $P P e-90$ \\
\hline Hemithea aestivaria ( $\mathrm{Hb})$. & -6.5 & -12 & - \\
\hline Staurophora celsia (L.) & -8.5 & +6 & PS-63, PK-85, PPe-83 \\
\hline Cyclophora pendularia (Cl.) & -9 & -17 & - \\
\hline Pararge achine (Sco.) & -10 & -15 & - \\
\hline Macdunnoughia confusa (St.) & -11.5 & -8.5 & $K n-77$ \\
\hline Protodeltote pygarga (Hfn.) & -11.5 & -11 & - \\
\hline Polypogon lunalis (Sco.) & -13 & -9 & ES-66 \\
\hline Acronicta strigosa (D. \& S.) & -13.5 & -9 & - \\
\hline Calamia tridens (Hfn.) & -21.5 & -12.5 & - \\
\hline Maniola jurtina (L.) & -25 & -19 & - \\
\hline
\end{tabular}


than among the fluctuants (Table 3:6/14), but the difference is not significant.

Table 2 is particularly interesting in two respects:

1. The results from the coastal and inland provinces are independent but very similar, thus indicating a spatial synchrony in most species. The over-all correlation from Tables $2-4$ is $r=0.705, P<0.001$. The values from the coastal provinces account for $49 \%$ of the variation in those of the inland provinces. In some cases, clearly different or even opposite values are present. For example, in Deileptenia ribeata, the results are contradictory purely on technical grounds; the species has not yet spread into the inland provinces, i.e. it has many 0-values. Gymnoscelis rufifasciata (see Heikinheimo 1981: table 2) and Hypomecis roboraria appear to have had true regressive phases in the inland. In Staurophora celsia the situation is interesting: the northeastward expansion is still continuing but in the south the species is declining (cf. Alcis jubatus below). In Aplocera praeformata, Lomographa bimaculata, Laothoe amurensis, Odontosia sieversi and Xestia sextrigata, the expansion is most vigorous in the inland provinces. Lopinga achine, Cyclophora pendularia and Spilosoma luteum have been most regressive in the inland provinces, and Calamia tridens on the coast.
2. The areal invasions, described as new provincial finds north of the coastal and inland belts, are clearly related to the population trends in these belts. The indices from the inland provinces in Tables $2-4$ account for $43.9 \%$ of the variability of the new provincial finds (regression model with Poisson error distribution). In general, slightly more provincial finds are noted among the Geometridae (1.76 finds/ species, S.E. $=0.261)$ than among Noctuidae $(1.4$, S.E. $=0.238)$.

Kaisila (1962) treated 32 species which he did not include in his tables 5 and 6; most of these are either nonfrequent or reed species, or otherwise unclear in their occurrence. Four of these have undertaken a strong expansion since Kaisila's study period (Table 4); these alone are responsible for 29 new provincial finds.

Some other species from this group, too local for purposes of the query, have shown signs of expansion. Thus, Autographa excelsa (Kretschmar) was in Kaisila's study known only from near the southeastern border of Finland, but is at present a regular species widely occurring in the provinces $E K$ and $E S$, and has also been found in the north in $P K$ in 1964 and $K n$ in 1994, and in the west in $U$ (Helsinki) in 1969, $V$ in 1988 and $E H$ in 1985. Apamea ophiogramma was found in $S t$ in 1966, EP in 1976, PS in 1985, $P K$ in 1986 and $P P e$ in 1985. Eulithis pyropata (Hübner) at present

Table 3. Increase/decrease values from the period 1961-1995 of 14 fluctuant species of Kaisila (1962: fig. 6). For explanations, see Table 2.

\begin{tabular}{llll}
\hline & V-EK & St-ES & New provincial finds \\
\hline Colotois pennaria (L.) & +15.5 & +22.5 & EP-75, PK-63, KP-95, Kn-94 \\
Noctua pronuba (L.) & +12.5 & +13.5 & Kn-68,PPe-69, PPp-88, Ks-92 \\
Archanara dissoluta (Tr.) & +8.5 & +8 & $S t-68, P S-76, P K-84$ \\
Laspeyria flexula (D. \& S.) & +7.5 & -3 & PS-74 \\
Pyrrhia umbra (Hfn.) & +7 & -8 & LK-93 \\
Atolmis rubricollis (L.) & +4.5 & -7.5 & - \\
Gynaephora selenitica (Esp.) & -1 & -1.5 & - \\
Miltochrista miniata (Forst.) & -1.5 & +1 & PH-89 \\
Fixsenia pruni (L.) & -2 & -3.5 & - \\
Argynnis paphia (L.) & -5.5 & -6.5 & SH-89 \\
Calliteara pudibunda (L.) & -6 & -9 & - \\
Eilema depressum (Esp.) & -9 & -5.5 & - \\
Rhyparia purpurata (L.) & -13 & -13 & \\
Trachea atriplicis (L.) & -13 & -13 & \\
\hline
\end{tabular}


occurs locally along the southern coast and has been noted in ES in 1970, LK in 1974 and PS in 1975 as well as in the west in $V$ in 1964 and $A$ in 1992. Amphipyra berbera and A. pyramidea (Linnaeus) have clearly spread eastward along the coast, with some inland finds.

\subsection{Species increased or decreased during 1961-1996 and not treated by Kaisila (1962)}

The distribution of new provincial finds between the $+/$ - groups is even more differential than in Table 2, 108/7 (Table 5); however, in this case the increase/decrease values and the new finds are partly from the same areas. They are interdependent, since the new finds have certainly affected the subjective rating of the species; therefore, this result is not statistically treated.

Most species new to Finland since Kaisila (1962) or rare species that have been showing expansions during recent times are neither included in the query nor published in the literature. Since 1961, 81 new macrolepidopterous species have been recorded in Finland (and 2 more in 1997, Table 6; species detected on taxonomical grounds not included), i.e. 2.25 species/year. They form relatively well-established groups:
1. Eight species of well-known migrants, e.g. Hyles lineata, Euchloe chloridice, as well as Heliothis nubigera and Helicoverpa armigera.

2. Thirteen windborne species of long-range irruptive character, with no native populations: some of them partly migrant in character (e.g. Iphiclides podalirius, Prodotis stolida, Eublemma purpurinum), some being very distant windborne specimens of species not known to migrate (Syngrapha ain, Cucullia fraterna, C. boryphora and Protexarnis squalida) and some being closely related to the following group (e.g. Lithophane semibrunnea).

3. Twenty-six species of short-range irruptive character, probably mostly windborne specimens from neighbouring countries, but with no native populations established, e.g. Ptilophora plumigera, Tyria jacobaeae and $\mathrm{Ho}$ risme vitalbata, as well as many other geometrids or drepanids.

4. Eight species which are rare locals or are about to gain a foothold in the country, e.g. Lycaena dispar (disappeared again?), Sideridis albicolon, Eugnorisma glareosum and Xylomoia strix.

5. Fifteen species have established local populations and many have been spreading, e.g. Orthosia munda apparently having spread from

Table 4. Species treated by Kaisila (1962), but not present in his figs. 5-6, which have recently been strongly expansive. For explanations, see Table 2. In the footnote, a brief distributional history for each species is given (additional species from this group mentioned in the text).

\begin{tabular}{llll}
\hline & V-EK & St-ES & New provincial finds \\
\hline Amphipyra perflua $^{1)}(\mathrm{F})$. & +20 & +25.5 & St-88, PH-90, PS-85, Kn-93 \\
Cryptocala chardinyi) $(B d v)$. & +12 & +26.5 & U-66, St-90, EH-72, ES-61, EP-93, PH-88, PS-76, PK-72 \\
Apamea scolopacina $^{3)}($ Esp.) & +10 & +5 & A-84, V-66, U-68, EK-81, EH-75, ES-79, LK-94, PH-85 \\
Mesoligia literosa $^{4}(\mathrm{Hw})$. & +8.5 & +18.5 & St-65, ES-64, EP-76, PH-91, PS-61, KP-95, PK-86 \\
\hline
\end{tabular}

1) In 1960, A. perflua was involved in a large immigration of many noctuids, e.g. Catocalas, and spread its population seeds widely over southern Finland (for local population increase, see Fernelius 1981: fig. 1).

2) Recorded as new to Finland in 1957, C. chardinyi was found singly during the early 1960 s on the southern coast (these were probably windborne specimens), but it simultaneously became established in southeastern Finland and began a rapid expansion westwards. During the 1980 s, it became locally abundant in the inland provinces, and in the 1990s also in southwestern Finland.

3) New to present-day Finland, A. scolopacina was recorded only in 1966 [Kaisila (1962) included it from the Karelian Isthmus]. It is now widespread in the coastal areas, but is also becoming increasingly common inland.

4) M. literosa was already recorded in 1915 on the southern coast and the present expansion mainly concerns inland provinces and the western coast. 
Table 5. Species that have shown the most increases and decreases since Kaisila (1962), according to the query (1st figure in parentheses) and to the literature (the 2nd figure). Species producing at least 5 observations in the same direction (those in opposite directions nullified each other, i.e. they have been removed pairwise) have been included. The last column shows new provincial finds from the period 1961-1996. One declining migrant treated by Kaisila has been included [ ]

\section{A. Increasing species}

Agriopis aurantiaria ( $\mathrm{Hb}$.) Autographa mandarina (Fr.) Cidaria fulvata (Forst.)

Erannis defoliaria $(\mathrm{Cl}$. Chloroclysta siterata ( $\mathrm{Hfn}$.)

Orthosia populeti (F.) Cerastis leucographa (D. \& S.) 10 Discoloxia blomeri (Curt.) Ennomos autumnarius (Wern.) Perizoma sagittatum (F.) Macrochilo cribrumalis ( $\mathrm{Hb}$.) Perizoma affinitatum (St.) Venusia cambrica Curt. Ourapteryx sambucaria (L.) Apocheima pilosaria (D. \& S.) Orthosia cerasi (F.)

Anticlea derivata (D. \& S.)

Xestia collina (Bdv.)

Acasis viretata $(\mathrm{Hb}$. Rivula sericealis (Sco.) Cosmia trapezina (L.) Rhizedra lutosa (Hb.) Spaelotis clandestina (Har.) Xestia xanthographa (D. \& S.)

$$
+18(13 / 5)
$$
$17(13 / 4)$ $16(11 / 5)$ $15(10 / 5)$ $14(13 / 1)$ $12(6 / 6)$

$10(7 / 3)$

$9(7 / 2)$

$9(4 / 5)$

8 (7/1) St-69, ES-75, LK-63, PK-63

8 (5/3) St-71, ES-73, LK-86, EP-83, PK-87

$7 \quad(5 / 2) \quad E S-76, P S-94$

7 (6/1) A-71, St-64, PPe-93

$7 \quad(6 / 1) \quad A-93, V-74, U-62, E K-61$, ES-76, LK-87, PK-86

$7 \quad(6 / 1) \quad V-87, U-66, E K-85$, St-93, EH-81, ES-74, LK-90

$7 \quad(5 / 2) \quad U-64, E K-83, E H-89$

6 (4/2) V-68, U-85 [Hankoniemi-87], PH-81

6 (6/-) V-95, U-71, EK-72, EH-73, ES-76, LK-71, PK-76

$5 \quad(2 / 3) \quad E P-71, K P-62$ [Pietars.]

$5 \quad(2 / 3) \quad K P-79, K n-92$

$5 \quad(2 / 3) \quad E P-75, K P-93, K n-64$

5 (2/3) PH-79, Kn-75, PPp-82

$5 \quad(3 / 2) \quad L K-88, E P-88, P S-71, P K-73, K P-95, P P e-76$

5 (4/1) ES-71, PK-65

\section{B. Decreasing species}

$\begin{array}{lrrll}\text { Issoria lathonia (L.) } & -16 & (11 / 5) & - \\ \text { Opigena polygona (D. \& S.) } & 11 & (9 / 2) & \text { PP-69 } \\ \text { Glaucopsyche alexis (Poda) } & 9 & (7 / 2) & \text { Ks-61 } \\ \text { Acronicta leporina (L.) } & 8 & (8 /-) & - \\ \text { Eremobina pabulatricula (Bra.) } & 8 & (8 /-) & - \\ \text { Spaelotis ravida (D. \& S.) } & 8 & (6 / 2) & - \\ \text { Hypodryas maturna (L.) } & 7 & (4 / 3) & \\ \text { Catocala pacta (L.) } & 7 & (5 / 2) & - \\ \text { Euxoa recussa (Hb.) } & 7 & (2 / 5) & - \\ \text { Lycaena helle (D. \& S.) } & 6 & (5 / 1) & \text { PH-61 } \\ \text { Clossiana freija (Thb.) } & 6 & (5 / 1) & - \\ \text { Erebia embla (Thb.) } & 6 & (5 / 1) & - \\ \text { [Acherontia atropos (L.) } & 6 & (1 / 5)] & - \\ \text { Apamea sordens (Hfn.) } & 6 & (3 / 3) & - \\ \text { Leucania comma (L.) } & 6 & (4 / 2) & - \\ \text { Parnassius apollo(L.) } & 5 & (4 / 1) & - \\ \text { Lycaena hippothoe (L.) } & 5 & (4 / 1) & - \\ \text { Limenitis populi (L.) } & 5 & (-/ 5) & - \\ \text { Baptria tibiale (Esp.) } & 5 & (4 / 1) & \text { ES-81 } \\ \text { Nola karelica Teng. } & 5 & (3 / 2) & \text { V-80, U-81, PS-61 } \\ \text { Moma alpium (Osb.) } & 5 & (2 / 3) & - \\ \text { Acronicta euphorbiae (D. \& S.) } & 5 & (4 / 1) & \\ \text { Acronicta rumicis (L.) } & 5 & (4 / 1) & - \\ \text { Mamestra brassicae (L.) } & 5 & (3 / 2) & - \\ \text { Mame } & & & \end{array}$


Table 6. Macrolepidopterous species new to Finland during the period 1961-1997, according to decades and collecting years (new species identified on taxonomical grounds, e.g. sister species etc., omitted; the 1997 species have been added provisionally and are not included in the statistics). After the species names, the following symbols are shown: the 1st symbol, character of occurrence in Finland: $m=$ migrant, li = long-range irruptions (from outside the Baltic countries-Sweden), si = short-range irruptions (from the Baltic countries-Sweden), $f$ ? $=$ foothold uncertain, $p=$ population established, $w=$ resident wetland species, $n=$ resident northern species. The 2 nd symbol, status in Finland: $\mathrm{O}=$ the only specimen, $\mathrm{M}=$ a few more known, $\mathrm{R}=$ unstable rarity, $\mathrm{S}=$ stable population, $\mathrm{E}=$ expanding species, $\mathrm{F}=$ fluctuating species. Optional 3rd symbol: $\mathrm{T}+$ number $=$ see Table $\mathrm{x}$ and $\mathrm{t}=$ see text. ${ }^{*}=$ unpublished finds.

\begin{tabular}{|c|c|c|c|}
\hline \multicolumn{2}{|l|}{$1961-1970$} & \multicolumn{2}{|l|}{$1971-1980$} \\
\hline 1961: Elaphria venustula (Hb.) & $\mathrm{f} ?, \mathrm{R}$ & 1971: Comibaena bajularia (D. \& S.) & si, M \\
\hline Ourapteryx sambucaria (L.) & $\mathrm{p}, \mathrm{E}, \mathrm{T} 5$ & Xestia collina (Bdv.) & $p, E, T 5$ \\
\hline 1962: - & & 1972: Lycaena dispar $(\mathrm{Hw})$. & $f ?, \mathrm{R}, \mathrm{t}$ \\
\hline 1963: Prodotis stolida (F.) & li, M & Eilema sororculum (Hfn.) & si, $R$ \\
\hline Cryphia algae (F.) & si, $\mathrm{O}$ & Herminia tarsicrinalis (Knoch) & si, $R$ \\
\hline Cosmia affinis (L.) & si, $\mathrm{O}$ & Trichoplusia ni (Hb.) & $\mathrm{m}, \mathrm{M}$ \\
\hline Sedina buettneri (Her.) & $w, R$ & Autographa mandarina (Fr.) & $p, E, T 5$ \\
\hline 1964: Hyles lineata (Esp.) & $\mathrm{m}, \mathrm{M}$ & Archanara geminipuncta (Hw.) & $w ?, M, t$ \\
\hline Heliothis nubigera Hr.-Sch. & $\mathrm{m}, \mathrm{M}$ & 1973: Araschnia levana (L.) & $p, E, t$ \\
\hline Eugnorisma glareosum (Esp.) & $f ?, R$ & Cilix glaucatus (Sco.) & si, $\mathrm{O}$ \\
\hline 1965: Habrosyne pyritoides (Hfn.) & $p, E, t$ & Horisme vitalbata (D. \& S.) & si, M \\
\hline Cryphia ereptricula (Tr.) & si, $\mathrm{O}$ & Narraga fasciolaria (Hfn.) & si, $\mathrm{O}$ \\
\hline Eublemma purpurinum (D. \& S.) & li, $M$ & ${ }^{*}$ Cucullia fraterna Butl. & $\mathrm{li}, \mathrm{O}$ \\
\hline Ipimorpha contusa (Fr.) & $p, F, t$ & Orthosia munda (D. \& S.) & $p, E$ \\
\hline Xanthia aurago (D. \& S.) & $p, E, t$ & Mythimna albipuncta (D. \& S.) & $\mathrm{m}, \mathrm{O}$ \\
\hline Noctua janthe (Br.) & $p, F$ & Agrotis cinerea (D. \& S.) & si, $M$ \\
\hline 1966: Epirrhoe tartuensis Möls & $w, R$ & 1974: *Everes alcetas (Hoff.) & li, O \\
\hline Discoloxia blomeri (Curt.) & $p, E, T 5$ & Tyria jacobaeae (L.) & si, $M$ \\
\hline Euchalcia variabilis (Pil. \& Mit.) & si, M & Xylomoia strix Mikk. & $f ?, M$ \\
\hline Apamea scolopacina (Esp.) & $p, E, T 4$ & 1975: Chesias legatella (D. \& S.) & si, M \\
\hline 1967: Costaconvexa polygrammata (Br.) & si, M & Peribatodes secundarius (D. \& S.) & $p, E, t$ \\
\hline Agriopis marginaria (F.) & si, $M$ & Orthosia miniosa (D. \& S.) & $f ?, R$ \\
\hline Helicoverpa armigera $(\mathrm{Hb})$. & $\mathrm{m}, \mathrm{M}$ & Lasionycta skraelingia (Hr.-Sch.) & $\mathrm{n}, \mathrm{S}$ \\
\hline Phragmatiphila nexa (Hb.) & $f ?, R$ & 1976: Horisme aemulata (Hb.) & si, $M$ \\
\hline Chortodes brevilinea (Fenn) & $w, S$ & 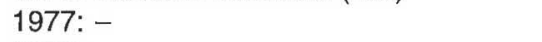 & \\
\hline 1968: Coenonympha hero (L.) & si, $\mathrm{O}$ & 1978: - & \\
\hline 1969: Selidosema plumarium (D. \& S.) & li, $\mathrm{O}$ & 1979: - & \\
\hline Peridroma saucia (Hb.) & $\mathrm{m}, \mathrm{M}$ & 1980: Xanthia gilvago (D. \& S.) & $p, R$ \\
\hline 1970: Euchloe chloridice (Hb.) & $\mathrm{m}, \mathrm{M}$ & Polia conspicua (A. B.-H.) & $n, s$ \\
\hline Euchalcia modestoides (Poole) & $\mathrm{p}, \mathrm{R}, \mathrm{t}$ & & \\
\hline Deltote bankiana $(\mathrm{F})$. & w, R & & \\
\hline
\end{tabular}

\section{1-1990}

1981: Acontia lucida (Hfn.) 1982: *Shargacucullia sp. nr. lychnitis li, O

1983: Noctua janthina (D. \& S.) Xestia brunneopicta (Mats.)

1984: Iphiclides podalirius (Sco.) 1985: Eupithecia irriguata $(\mathrm{Hb}$.

1986: Ptilophora plumigera (D. \& S.) Atypha pulmonaris (Esp.)

1987: *Hoplodrina ambigua

1988: Protexarnis squalida (Gn.)

1989: Epirrhoe rivata (Hb.) 1990:Eupithecia cauchiata (Dup.) li, $\mathrm{O}$

si, $R$

n, S

li, $\mathrm{O}$

f?, $\mathrm{O}$

si, $\mathrm{O}$

li, $M$

si, O

Ii, O

w, R

$p, R$

\section{1-1997}

1991: Amphipyra livida (D. \& S.)

1992: Peribatodes rhomboidaria (D. \& S.) Cornutiplusia circumflexa (L.) Aporophyla lutulenta (D. \& S.) Lithophane semibrunnea ( $\mathrm{Hw}$.) Hadena irregularis ( $\mathrm{Hfn}$.)

1993: Drepana binaria (Hfn.) Cucullia boryphora Fsch. de W. Sideridis albicolon (Hb.) Noctua interposita (Hb.) 1994: Syngrapha ain (Hoch.) 1995: -

1996: Lacanobia splendens (Hb.) Hadena luteago (D. \& S.)

1997: Mormo maura (Linnaeus) Noctua interjecta Hübner si, $\mathrm{M}$

f?, O

$\mathrm{m}, \mathrm{M}$

si, $\mathrm{O}$

li, 0

si, $\mathrm{O}$

si, 0

li, $\mathrm{O}$

f?, M

li, $\mathrm{O}$

Ii, $\mathrm{O}$

si, $\mathrm{O}$

f?, $\mathrm{M}$

li, O

si, $\mathrm{O}$ 
western Estonia, and 4 others from the direction of the Åland Islands, e.g. Peribatodes secundarius.

6. Seven wetland species, one of which has been mainly windborne (Archanara geminipuncta; a local population detected only in 1997).

8. Three species are boreal (Lasionycta skraelingia, Polia conspicua and Xestia brunneopicta); all are native but, if any, the last-mentioned may have recently spread from the east.

Around one third, or 26 of the new species, have been encountered only once in the country (symbol $\mathrm{O}$ ), most of these expectedly detected only recently. Of 24 additional species a few more specimens have been found (M), and 15 additional species are considered as more or less unstable rarities (R). Ten species are expanding (E) and 2 behave as fluctuants $(F)$; all these have been found latest in the 1970 s. Three northern species seem to have stationary populations.

Some of the most recent expansions have come from the direction of the Åland Islands and Sweden. Peribatodes secundarius (D. \& S.) was first found in 1975 in the southwestern archipelago, at $V$ : Houtskär, and the following year at the Alland Islands where it was collected in substantial numbers in the 1980s. The extreme points are already on the western coast in St: Ahlainen, inland in $E H$ : Orivesi and midway on the southern coast at $U$ : Porvoo. Within ten years it will probably be a common species throughout the whole of southern Finland. Campaea margaritata (Linnaeus) has expanded with similar rapidity, although it was first recorded at $A$ : Mariehamn, already in 1939. It was discovered in the province $V$ in 1983 and $U$ in 1988 and has shown massive outbreaks on some islands. The furthest points are at St: Reposaari (1993) and $U$ : Porkkala (1996), while that from $E H$ : Valkeakoski (1993) may have been of an irruptive moth.

In this context, a subspecies new to Finland should be mentioned. Chloroclystis v-ata (Haworth) has been known from Finland as a local population at $V$ : Karjalohja, considered as a relict from earlier warmer periods and described as a new subspecies, ssp. relicta, by Krogerus (1996). The nominate subspecies was encountered for the first time in Finland in 1985 at $U$ : Sipoo, possibly a windborne specimen, however, at least two observations are known from A: Lemland since 1992.
It is feared that this expansive subspecies, the legal protection of which has been cancelled in 1997 , will replace and annihilate the local subspecies by hybridization (Krogerus 1996). In most cases, subspecies described from the Baltic area are well isolated from the nominate subspecies; those of Eupithecia pernotata enictata Pellmyr \& Mikkola, 1985 and Chersotis andereggii arcana Mikkola, 1987 occur in the Alps.

Three noctuid and one butterfly species probably spread from the $\AA$ land Islands already in the sixties: Orthosia cerasi (reached $E H$ in 1994), $O$. cruda, Agrochola macilentus (EK-94) and Quercusia quercus (Linnaeus). They were originally known from Åland only, but are now widespread on the southern coast. Xanthia aurago was found in Åland only in 1965 and was recorded at $V$ : Houtskär in 1983, at $U$ : Hanko in 1994 and at St: Ahlainen in 1996. Some other species that were previously observed mainly in §̊land are now quite regularly observed in the outer archipelago of the Gulf of Finland, e.g. Apamea lithoxylaea (D. \& S.), Lithophane ornitopus (Hufnagel) and Conistra erythrocephala (D. \& S.).

Discoloxia blomeri and Apamea scolopacina, which were recorded as new to Finland in 1966, are now widespread in southern Finland. Amphipyra perflua has been still more efficient in its increase (see Table 4); it has simultaneously widened its habitats, first from the best luxuriant deciduous forests (Mikkola 1966) to gardens etc., and then to normal mixed forests and even to peatbog margins.

The noctuid Euchalcia modestoides has been found, after its first find in Helsinki in 1970, mainly in a remarkably small area in mid-southern Finland: Porvoo-Askola-Vihti. The first record of Paradarisa consonaria was made at EK: Vehkalahti in 1960, and the species has spread along the coast westward to $V$ : Nauvo (1985). Habrosyne pyritoides appears to be still more tightly bound to the sea belt: its first record is from Helsinki in 1965 but it is known to occur throughout a line from the Åland Islands (Sottunga) to $E K$ : Pyhtää. Found first in EK: Tammio in 1962, Ourapteryx sambucaria spread clearly from the southeast and at present occurs in the southeast also deeply inland (ES: Savonlinna, PK: Kitee) but in the west mainly along the coast, and was found in 1993 as new to the Åland Islands. 
Recently for the first time a butterfly, Araschnia levana, has been spreading to Finland, both from the southeast and the south. The species was first observed at $E K$ : Lappeenranta in 1973, but its first local population was detected ten years later at $P K$ : Ilomantsi. In 1992, it had spread to Tohmajärvi and Värtsilä in the east and was for the first time observed in the south, in Helsinki and $U$ : Kirkkonummi (4 exx.). In 1993 and 1996 the species has been observed near $U$ : Porvoo and at $V$ : Hiittinen. The status of Lycaena dispar, a legally protected species, is unclear; it was first observed at two localities in the southeast in 1972 , and the first population was detected in 1975. The population did well until the early 1980 s but then declined - probably due to an adverse change in habitat - and the last specimens in that area were seen in 1988; in 1996 the species was again seen in the southeast. Iphiclides podalirius is probably solely a migrant; after the initial discovery in 1984 some specimens have been seen in the mid-1990s and in 1997.

Not all expansions proceed directly to the north, northeast or northwest. An entire group of species exists that was decades ago encountered exclusively inland; of these, the following are listed in Table 5: Venusia cambrica, Cerastis leucographa (these two were already mentioned by Kaisila 1962: 389), Anticlea derivata and Ennomos autumnarius. Other northern species that come down to the southern coast include Chloroclysta infuscata (Tengström) (occurring also outside peatbogs), Nola karelica (e.g., outer skerries off Porvoo in 1961; new to Helsinki in 1981) and Autographa macrogamma (Eversmann) (new to A 1984). Blepharita amica (Treitschke) has mainly spread westward along the southern coast (V1985) but has recently been found in the provinces $E H$ (1996) and Kn (1995).

\subsection{On the time scale of population changes}

The expansions and increases are, of course, not always steady and continuous, but there may occur long regressive periods, and the species may be absent for years. Some species treated by Kaisila (1962), e.g. Hemithaea aestivaria, Rhyparia purpurata and Trachea atriplicis showed their highest frequencies during the 1940 s and the first half of the $1950 \mathrm{~s}$. Rh. purpurata was totally absent between 1961 and 1996, except 2 exx. from southeastern Finland in 1972-1973 and 6 exx. from the southern coast in 1992 to $1997 ;$ T. atriplicis was practically absent during 1975-1989, and appears to be recovering in the 1990s. Polypogon lunalis also appears to be returning: it was found in $A$ in 1993 and at $V$ : Lohja in 1996 (but at $V$ : Dragsfjärd it has occurred steadily).

During the period 1961-1996, Xestia sexstrigata made a strong expansion but, mainly in the south, has experienced a regression since the late 1970s (see Fernelius 1981: fig. 1 and Heikinheimo 1981: table 2). Catarhoe rubidata was absent for a large part of the 1980 s but has increased again, especially in the east. Herminia tarsipennalis was absent during 1977-1989 from ES: Mäntyharju and H. tristalis during 1962-1982. Even quite common species may experience long regressions: Ennomos alniarius (Linnaeus) appeared to be totally absent during the early 1990s and Aglais urticae quite infrequent in the late 1980s: according to rumors, the latter regression extended to Voronezh in southern Russia. One of the longest recent absences was recorded for the geometrid Scopula decorata (D. \& S.), already considered extinct in Finland: the last specimen from the continent was collected in 1965, and from $V$ : Hiittinen, Örö in 1971, until it was rediscovered in the latter locality in 1996 (Kullberg 1997). Similarly, Agriopis aurantiaria was not, as far as is known, found in the Helsinki area during the period 1939-1969, nor Ennomos autumnarius in the decades before 1966.

Urbahn (1971) emphasized that Opigena polygona may be absent for decades. Since it was new for the province PPe in 1969, it has been found only sporadically on the southern coast until a few moths were observed in 1996. In Denmark the species was not observed between 1942 and 1970 , was common during the 1980 s, but in 1992 only 3 specimens were observed in the country.

In some cases, it appears that expansion by a new species would result in an earlier common species becoming rare, which probably occurred with Amphipyra tragopoginis (Clerck) and Amphipyra perflua. The common tortricid of dry meadows in southeastern Finland, Aethes tesserana (D. \& S.) appears to have disappeared while the related Cochylis hybridella (Hübner) has become 
more common. Such cases should not, however, be taken as straightforward examples of interspecific relations because it is possible that climatological changes favourable to one species are simultaneously disadvantageous for the other.

Ahola et al. (1983) provided interesting data on short-term variations, first stating that many species show maximal years that exceed the average frequency 5-12-fold and are usually followed by a deep crash; usually only one such year per species was included in their study period of 1969-1982 (when all specimens were counted from a number of light traps). Of the species treated by Kaisila (1962), Gymnoscelis rufifasciata showed a 12-fold increase in 1973, and Perizoma sagittatum a 5-fold increase in 1982; Amphipyra tragopoginis attained a 5-fold increase in 1970 (the curve of Fernelius, 1981: fig. 1, also showed a high frequency for that time).

Furthermore, Ahola et al. (1983) listed (three primitive moths left away) 63 species in an increasing phase and 63 species in a declining phase during four final years, 1979-1982 of their study, resulting in an opportunity to estimate how far a four-year course may reflect expansions and regressions. The lists of species increasing/decreasing at $E H$ : Koski were compared with the data collected for the period 1961-1995 (where possible, with the inland results), and the species coinciding with the score for the longer period were listed separately. The statistics is as follows:

Of 63 increasing species $12(19.0 \%)$ coincided with the long-term score.

Of 63 decreasing species $9(14.3 \%)$ coincided with the long-term score.

Total: For 126 species, 21 (16.7\%) "correct" scores.

Although many uncertainties occur in the details of this comparison, I cannot see any reason why the general result would not hold: only about one sixth of the 4-year trends inside a 14-year study coincide with the long-term ones from a wider geographical area. This would mean that the results from Koski mostly denote local population fluctuations that are not necessarily synchronized over wide areas. This is why studies such as that by Heikinheimo (1981) covering 8 years from $E H$ : Janakkala and 6 years from $U$ : Vantaa are of limited use when long-term changes are analysed. On the other hand, of Heikinheimo's 9 species new to the localities, 8 are treated as expansive in this paper, Hillia iris (Zetterstedt) being the only "extra" species.

\subsection{Parallel phenomena in neighbouring countries}

As shown in Table 7, many expansions take place synchronously or successively in Finland and Sweden, and some can be traced to Denmark. Peribatodes secundarius and Chloroclystis $v$-ata are the best examples of these, both having also expanded into Estonia. Similarly, expansions of eastern species inside Finland are often later reflected as discoveries of species new to Sweden, e.g. Aplocera praeformata (Up-77, Sö-80, Hr-96, Gä-96), Blepharita amica $(U p-84)$ and Eulithis pyropata (Go-93).

As expected, Autographa mandarina was detected in Estonia about the same time (Tartu 1973) as in Finland, later spreading through the Estonian mainland during 1981-1985 (J. Viidalepp unpubl.). Three species expanding in Finland have probably spread from the northwest into Estonia: Mesoligia literosa was first found in 1977 and Campaea margaritata in 1995, both in western Estonia, although the latter may have spread from the south, and Peribatodes secundarius was discovered at Saaremaa in 1996 (several specimens). Many species recently expansive in Finland increased in numbers in Estonia and Latvia during the 1960s and 1970s: Orthosia munda and miniosa, Xanthia aurago and gilvago, Agrochola macilentus, Apamea scolopacina and ophiogramma (Viidalepp 1970, Sulcs et al. 1981).

Some of the species clearly expansive in Finland, such as Habrosyne pyritoides, Chloroclysta siterata, Agriopis aurantiaria and Lithophane ornitopus are not reported from the Leningrad Area by Derzhavets et al. (1986). The presence of three autumn species among these points towards less effective sampling in that area. Apamea scolopacina was found in Petrodvorets, $20 \mathrm{~km}$ east of Leningrad, for the first time in the years 1979 and 1981, and Lacanobia splendens in Beloostrov, $20 \mathrm{~km}$ northwest of Leningrad, in 1973.

One of the geographically widest expansions is that of Eupithecia sinuosaria: the second phase 
of the expansion has led to invasion into Switzerland and northern Italy (Rezbanyai-Reser 1989).

\subsection{Changes in microlepidopterous fauna}

As the query did not produce results comparable with the macros, a brief report is given based mainly on discussions with some specialists (on the hepialids on my own file).
The areal changes of hepialids are well known. Hepialus humuli (Linnaeus) is one of the few lepidopterans that spread to Finland both from the southwest and southeast. Tengström (1869) knew it both from the Åland Islands and from Southern Karelia. Clayhills (1957), however, reported the species from the central parts of province $U$, namely from Helsinki and Espoo (an importation?). In a 1962 supplement he added three communes, two of them from the west and east, and in 1967 and

Table 7. Some expansions parallel to the Finnish expansions during the period 1961-1995 in the Swedish and Danish faunas according to the yearly or ten-year reports of Svensson, Palmqvist and Ryrholm (Opuscula Ent., Ent. Tidskr.; Sweden $=\mathrm{S}$ ) or of the teams of Kaaber or Knudsen et al. (Lepidoptera) or according to Fibiger and Svendsen 1981, Skou 1991 (Denmark = DK). Expansions expressed as new provincial finds.

\begin{tabular}{|c|c|}
\hline Araschnia levana (L.) & $\begin{array}{l}\text { S: New Sk-82 } \\
\text { DK: NEZ-78 }\end{array}$ \\
\hline Habrosyne pyritoides (Hfn.) & S: Up-84, Vg-85, Sö, Ög-86, Ds-87, Vs-96 \\
\hline Cidaria fulvata (Fors.) & S: Vr-78, Da, Vb, Ås-86 \\
\hline Chloroclystis v-ata $(\mathrm{Hw}$.) & $\begin{array}{l}\text { S: New Sk-79, BI, Ha, Öl-83, Vg-84, Go-89, Sm-93, Bo-96 } \\
\text { DK: New LFM-73, B-76, WJ-78, EJ, NWZ, SZ-79, NEJ-80, SJ, NEZ-81, NWJ-83 }\end{array}$ \\
\hline Discoloxia blomeri (Curt.) & S: Up-80, Vs, Da-84, Sm-85, Öl, Ds, Sö, Ga-89, Vg-93, Ög-94 \\
\hline Cepphis advenaria $(\mathrm{Hb})$. & S: Vr-80, Dr, Go-85, Gä-88 \\
\hline Ennomos autumnarius (Wern.) & $\begin{array}{l}\text { S: Vs-77, Vg-78, Hs-83, Bo-85 } \\
\text { DK: WJ-66, NWZ-69, NEJ-70, B-74, NWJ-77 }\end{array}$ \\
\hline Peribatodes secundarius (D. \& S.) & $\begin{array}{l}\text { S: Sö-73, Ög, Nä, Da-74, Up-75, Vs-76, Ds-78, Vg-81, Bo-91, Gä-94, Hr-96 } \\
\text { DK: WJ-68, NEJ-69, NWJ-77 }\end{array}$ \\
\hline Alcis jubatus (Thb.) & S: $M e-80, P i-88, H r-89$ \\
\hline Paradarisa consonaria $(\mathrm{Hb})$. & $\begin{array}{l}\text { S: Up, Vg-81, Vs-91 } \\
\text { DK: Jylland, SJ-71 }\end{array}$ \\
\hline Lomographa bimaculata (F.) & S: $D a-70, V r-83$ \\
\hline Odontosia sieversi (Mén.) & S: $M e-84, B o, D s-86, H r-87, A ̊ n-88$ \\
\hline Macdunnoughia confusa (St.) & $\begin{array}{l}\text { S: } M e-74, V r-86 \\
\text { DK: } B-61, E J-64, F-69, S J-78, N W J-82\end{array}$ \\
\hline Autographa macrogamma (Ev.) & $\begin{array}{l}\text { S: Gä-78, Öl-84, Go-85, Sö-90, Nä-92 } \\
\text { DK: New NEJ-95 }\end{array}$ \\
\hline Autographa mandarina (Fr.) & $\begin{array}{l}\text { S: New Up-80, Go-81, Öl-82, Sk-83, Sm, Sö, Da-86, Hr-89, Ha-91, Vs-92 } \\
\text { DK: New B-81, LFM-82, NEZ-88, NWZ, SZ-91 }\end{array}$ \\
\hline Amphipyra perflua (F.) & $\begin{array}{l}\text { S: Go-86, Up-88, Bl-89, Vr-96 } \\
\text { DK: L-68, NEJ-82 }\end{array}$ \\
\hline Apamea scolopacina (Esp.) & $\begin{array}{l}\text { S: Bo-78, Go-80, Sö-84, Up-87, Nä, Ög-93 } \\
\text { DK: NEJ-68, NWJ-72 }\end{array}$ \\
\hline Agrochola macilentus $(\mathrm{Hb})$. & S: $D r-71, V s-77, B o-78, V r-82, V b-92$ \\
\hline
\end{tabular}


1968 the species was observed for the first time at Tammisaari in the west and Porvoo in the east, respectively. In $1966 \mathrm{H}$. humuli was observed at $E S$ : Mäntyharju. With a find from $E H$ : Asikkala in 1971, the two areas began to coincide in the inland. Hepialus lupulinus (Linnaeus), found for the first time in the country in Helsinki in 1972, later at $E H$ : Lahti and recently at $E K$ : Virolahti, has probably been imported with tuberous roots.

Many of the new and expanding species of microlepidoptera feed as larvae on planted trees or imported grasses. Caloptilia hemidactylella (D. \& S.) and Ypsolopha chazariella (Mann) feed on Acer and Gypsonoma oppressana (Treitschke) on Populus. The yponomeutid protected on the Åland Islands, Scythropia crataegella (Linnaeus), living e.g. on Prunus spinosa, has increased rapidly in $A$ and has already been found in $V$ : Turku. Three tortricids have increased; Cochylis hybridella, Lobesia abscisana Doubleday and Eucosma campoliliana (D. \& S.) feed on asteracean plants, and the expanding momphid Mompha divisella Herrich-Schäffer on Epilobium adenocaulon. Two case-bearers, Coleophora badiipennella (Duponchel) and $C$. limosipennella (Duponchel) feeding on Ulmus, possibly have appeared only recently in the Åland Islands. Two species observed only during the 1990s in the southwestern archipelago, Syndemis histrionana (Frölich) and Depressaria emeritella Stainton, may expand to the continent in the near future.

Those microlepidopterans in decline constitute relatively clear ecological groups. Many anthropophilous moths have decreased: the tineid Trichophaga tapetzella (Linnaeus), feeding e.g. on eider down, has probably disappeared and the pyralid Pyralis lienigialis (Zeller) and the oecophorine Endrosis sarcitrella (Linnaeus) living mainly in cowsheds are declining. The host plants of some species have declined; thus, the oecophorine Agonopterix laterella (D. \& S.), feeding on Centaurea cyanea, is considered extinct in the country, and the tortricid Cydia discretana (Wocke), feeding on Humulus, is declining. Of the many declining species living in meadows the following should be mentioned: the adelid Nemophora cupriacella (Hübner) and the pyralid Diasemia reticularis (Linnaeus) as well as two tortricids which have probably disappeared: Aethes tesserana and Cydia lunulana (D. \& S.).

\section{Discussion}

This is probably the last survey of population changes of Finnish Lepidoptera based on a query and on literature data. Both night-flying macrolepidopterous moths and butterflies are at present monitored yearly (Söderman et al. 1995, Marttila \& Saarinen 1996), and thus, future reports may appear on a more numerical basis. Irrespective of the monitoring programmes, the present article provides proof of the permanent value of longterm collecting in the same locality combined with thorough notations.

\subsection{Expansive and fluctuant species}

Results on the re-examination of the so-called expansive and fluctuant species of Kaisila (1962) dispute this division, which appears to be based on a historical aspect rather than on a biological difference. When a certain species has invaded an area in the north, it is there, i.e. it can no longer perform an expansion (in the strict sense) to the same area and supposedly will become a more or less fluctuant species. Actually, such species may have visited the country many times before the first historically observed expansion. The other extreme is formed by species of which the yearly fluctuations (in abundance or distribution) do not differ from those of the species of the local fauna; therefore, some of the latter may be relatively recent expansion species.

Comparison of the observational history of the night-flying vs. day-flying migrants indicated the difficulties in separating spreading of the species from the development of collecting efficiency and methods. The day-flying migrants have been observed in Finland around fifty years earlier than corresponding night-flying species. In many cases a seemingly even progression, an "expansion", is nothing more than the technical speed at which the species was observed; e.g. in the 19th century, Finnish inland areas were much more poorly sampled than the coastal areas (Kaisila 1962). The observational history of a less frequent but old species may thus appear as a northward progression.

Those species questionably included by Kaisila (1962) as expansive species, particularly a number of noctuids from the second half of the 1800 s, 
act as a background noise in his study. A sharper signal, i.e. better discrimination of true expansions, would probably have rendered the effect of the ikosaionic climate change more clear. The recent material is basically different, because appearance of a new species is usually preceded by a significant number of empty years, often decades, at the same locality.

\subsection{The spatial synchrony}

The present data reveal that the population trends of Lepidoptera show spatial synchrony over a scale of at least $100-300 \mathrm{~km}$ (Fig. 1). The finds from the provincial belts $V$-EK and $S t-E S$ have mainly been spaced about $100 \mathrm{~km}$ apart. The positive trends in these belts lead to new provincial finds north of the belts, about $300 \mathrm{~km}$ from the southern coast.

In Finland, corresponding or even wider spatial synchrony has previously been documented at least in microtine rodents (e.g. Heikkilä $e t$ al. 1994) and in tetraonid birds (Lindström 1994). From elsewhere, moths and aphids, many butterflies and carabid beetles as well as a crab species can be added (Hanski \& Woiwod 1993 and references therein). Pollard (1991) observed that the local factors have little influence compared with the widespread factors, and Pollard et al. (1993) estimated that the synchrony may extend from Britain as far as the Netherlands. Recently, Sutcliffe et al. (1996) have analysed local and regional synchrony in British butterflies and noted that regional synchrony declines very slowly with distance.

As concluded in the above studies, the synchrony is supposedly caused by spatially correlated climatic conditions. Proof of action of such widespread factors is constituted by the fact that local moth faunas tend to vary as synchronous components related to the overwintering stage (Marttila 1991, Bruun 1992). As these are composed of taxonomically nonrelated subcomponents, it can be concluded that the variation must be caused by hibernation conditions.

The new provincial finds indicate that the positive population trends are correlated with increased mobility (migration), something that could not be shown in the earlier studies. The synchrony itself can hardly be explained by migration but, rather, the positive trends cause mobility. The expansion may occur through increased individual numbers, thus based on a statistical probability, or through increased mobility, or both. The new finds can hardly be explained simply by higher population densities in the province in question, since: (1) they are usually preceded by decades of negative observation, (2) they are often accompanied by further finds in the near future, indicating colonization, and (3) they are correlated with a general northward spreading of the species.

Hanski and Woiwod (1993) observed that the geometrids were less synchronized at long distances than the noctuids. This is hardly the case in the present material, since the most positive trends (the index +6 or more per species) are divided between noctuids and geometrids in the ratio $20: 20$; the per species rate of new provincial finds is, surprisingly, higher in the geometrids than in the noctuids (see Section 3.1.).

\subsection{Past and present faunal changes in Finland}

During the late 20th century, the lepidopterous fauna of Finland appears to be undergoing a dynamic phase in which it is probably affected by environmental changes and by local aspects of global climate change (Fig. 2). At least two species new to Finland have arrived from the southwest in the period 1961-1996, and 8 other southwestern species are spreading to or are already in the continent (thus $2 / 8$ species; the new subspecies Chloroclystis v-ata $v$-ata not included). Six new and 5 earlier species are expanding their areas from the south $(6 / 5)$, while from the southeast and east, 7 new species ( 3 now relatively stable) and 3 older species are spreading (7/3). Simultaneous, recent expansions of about 30 macrolepidopterous species are going on, and from Kaisila's (1962) species pool, about 40 expansive species (including those with values of +6 or more) must be added. Thus, about 70 species at present show signs of expansion.

We have neither standards nor materials for comparison about how many species should be spreading at any particular time. One possibility 


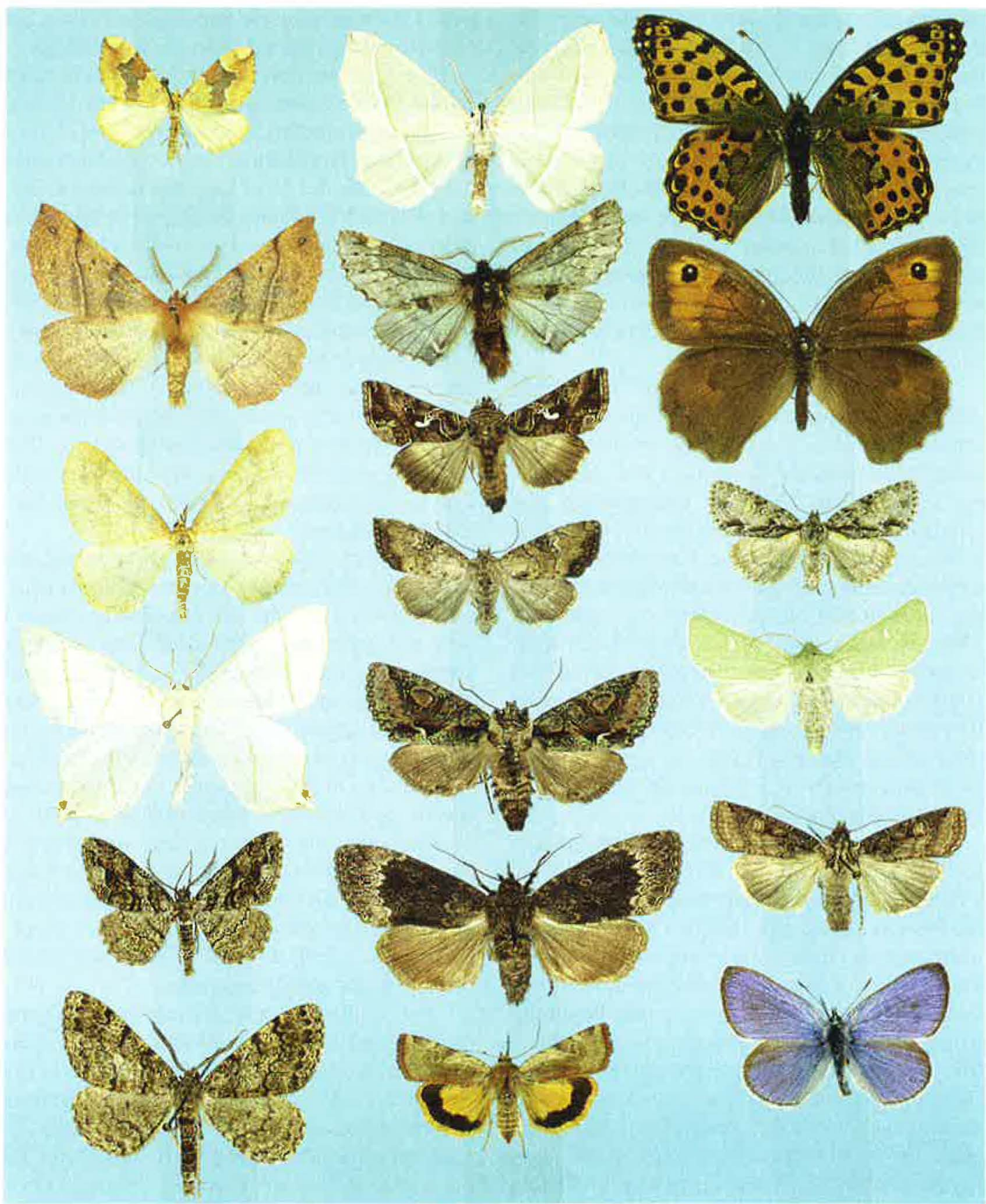

Fig. 2. Butterflies and moths increased (first 2 columns) and decreased (3rd column) in Finland:

Column I: Cidaria fulvata, Colotois pennaria, Agriopis aurantiaria, Ourapteryx sambucaria, Peribatodes secundarius and Deileptenia ribeata.

Column II: Campaea margaritata, Odontosia sieversi, Autographa mandarina, Apamea scolopacina, Meganephria oxyacanthae, Amphipyra perflua and Cryptocala chardinyi.

Column III: Issoria lathonia, Maniola jurtina, Acronycta strigosa, Calamia tridens, Opigena polygona and Glauchopsyche alexis. 
of tracing for a faunal balance is to also count the declining species. The difficulty is that the rare/ declining species are not included in a query with the same probability as those increasing. Therefore the species included in the classes Extinct, Endangered, Vulnerable or In need of monitoring/declining in the Finnish Red Data Book (Rassi et al. 1992) but not present in the query (Tables $2-5$ ), are added to those declining; 21 such species exist. The tables have 30 species with values of -6 or lower, so there would be a total of 50 declining species, which is well below the 70 expanding species.

The 10 -year totals of new provincial finds (Tables 2-5) supposedly describe some historical trends in the fauna. The new finds are divided into different decades as follows: the 1960s 45, 1970s 44, 1980s 44 and 1990s 34. Unexpectedly, the climatic advantageousness of the first half of the 1970s is not evident in these numbers. All the earlier decades show an average of about 4.5 finds per year but that of the 1990s is 5.67 per year. Thus, with even speed in the 1990s 57 new finds would be obtained. The high number of the $1990 \mathrm{~s}$ is mainly caused by Kaisila's species pool (compared with Table 5: 20/14). It is difficult to determine whether the rise is real, i.e. a consequence of climatic change, or artificial, i.e. caused by increasing collecting efficiency.

A similar test can be made with species new to Finland (Table 6): the 1960 s 30, 1970s 25, 1980s 12 and 1990s 13. The corrected number for the $1990 \mathrm{~s}$ is 22 , showing that the 1990 s again have a substantial increase over the previous decade. The possibility should be considered, however, that the pool of potential species may be diminishing. Svensson (1977) considered it self-evident that "it will be difficult to reach ten new species in the next decade because it can be assumed that there are very few local species left to be discovered". On the other hand, the increasing efficiency of collecting methods, particularly those utilizing automatic traps, is expected to reveal increasingly the migrants and especially the casual immigrants, i.e. the often windborne specimens of species that never gain a foothold in the country. If the moreor-less resident species (symbols R, S, E, F) are removed, the ten-year figures are 15, 13, 9 and 13 ( 3 of these may already be resident, $f$ ? in Table 6). The high figure of the 1960 s may remain a reflec- tion of the beginning phase of light-catching, but otherwise the 1990s are the most outstanding.

The environmental change that might have caused the most increases is the so-called BushFinland syndrome, a widespread decrease of open habitats and afforestation, as evidenced in Tables $2-5$. If we choose 35 of the most increased species, $19(54.3 \%)$ of these prefer trees and bushes as larval host plants, whereas $14(40 \%)$ feed mainly on grasses (two are very polyphagous); on the other hand, of 27 declining species only $5(18.5 \%)$ feed on trees and bushes and $22(81.5 \%)$ on grasses (including woody shrubs; the difference is significant, Fisher's exact test: $\mathrm{P}=0.003$ ). Thus, the treeand bush-feeding species fare better in presentday Finland than the grass-feeding species. The decreasing species appear to be more stenotopic than the invaders and, therefore, more sensitive to habitat changes.

Host plant quality may be partly correlated with the population trends in various lepidopterous groups (cf. also the microlepidoptera above): only one geometrid is included in the declining species, Cyclophora pendularia, but 17 are included in the increasing species. The expansive geometrids appear not to belong to any particular distribution type (cf. grouping by Sulcs \& Viidalepp 1972). On the other hand, in the increasing species no butterflies are present (Araschnia leva$n a$ and some others are not represented in the query), but 8 of them are present in the declining species. Two environmental reasons are evident for the declines: the draining of peatlands ( 2 species in the query) as well as overgrowth and change of meadows ( 6 species).

The decline of butterflies has been a general phenomenon in Finland and probably in the whole of Central and Northern Europe (cf. Urbahn 1973); Krogerus (1989) observed that in southwestern Finland the mean of summer totals of butterfly species for the period 1958-1972 was 43, but for the period 1973-1987 it was 33. Marttila et al. (1990) estimated that nearly half our resident butterfly species are declining or threatened. During the 1990s, the butterflies may again have fared better, e.g. Apatura iris has, at least temporarily, returned to Finland.

In the background, many declining species supposedly display the so-called metapopulation dynamics, studied in Finnish butterflies by Hanski 
et al. $(1994,1995)$. In night-active moths, particularly the fast-flying noctuids, this type of population structure is not equally probable, although it may be attained, e.g. in the archipelagoes and where the host plant is growing in isolated patches (Nieminen 1996). In the present material, Baptria tibiale (Table 5), Polypogon lunalis (Table 2) and Gynaephora selenitica (Table 3) appear to be good candidates for showing metapopulation dynamics.

Where then is the effect of the climatic change (cf. IPCC 1996)? The high rate during the 1990s of new provincial finds and of species new to the country constitute evidence as to the effect of the climatic change, as opposed to an even postglacial spreading. Of course, the latter may be accelerated as a consequence of the climatic change.

In the increasing species, a disproportional number of late-autumn and early-spring species occurs (9), whereas only one of these occurs among the declining ones, Orthosia gracilis. As the autumn and spring species are particularly numerous in the extreme western and eastern parts of the Palaearctic Region (Kononenko \& Mikkola 1992), it seems that these species require long, maritime autumn and spring seasons. Since the climatic change has in the northern latitudes primarily affected the winter and spring seasons (IPCC 1996), the good success of these species could be the first sign of climatic effect at these latitudes, while prevalence of southwestern elements points towards the same direction.

Parmesan (1996) has shown that in the checkerspot butterfly Euphydryas editha there have been more extinctions among the southern populations than in the north. She emphasizes that "it is the net extinction rate that is of interest in the context of global warming". This trend is not (yet?) visible in the Finnish Lepidoptera, since the declines, several of them observed in northern butterflies, seem rather to be caused by habitat changes.

Acknowledgements. I am particularly indebted to $\mathrm{Mr}$. J.-P. Kaitila for notes on microlepidoptera, Mr. P. Vakkari for help in the statistical treatment, Mr. P. Malinen, S. Repo, O. Peltonen, J. Itämies, S. Kontiokari, Kai Kulmala and O. Marttila for checking of provincial finds, J. Pöyry for notes on species new to Finland, L. Kaila, J. Kullberg, J. Viidalepp (Tartu) and G. Palmqvist (Stockholm) for useful notes on the manuscript, the two latter colleagues also for information about recent finds, and Dr. James Thompson for checking my English. For answering the query, I am grateful to the following observers: H. Alin, K. Helomaa, T. Ilonen, J. Kettunen, L. Kohonen, M.-L. Koivu, H. Koski, H. Krogerus, A. Kullberg, J. Kärkäs, L. \& E. Laasonen, R. Leinonen, J. Lemström, L. Luukkonen, J. Makkonen, P. Malinen, R. Martikainen, O. Marttila, K. Mikkola, V.-M. Mussalo, K. Nissinen, M. Nukarinen, O. Peltonen, K. Ruohomäki, J. Salokannel, I. Seuranen, K. Silvonen, M. Suoknuuti, H. Turunen, P. Utrio and E. Vanhala.

\section{References}

Ahola, M., Silvonen, K. \& Vilén, J. 1983: Kosken Hl (EH) pitäjän suurperhoset vuosina 1969-1982. — Not. Entomol. 63: 145-175.

Ander, K. 1944: Svensk fjärilsforskning 200 år. — Opusc. Entomol. 9: 57-78.

Ander, K. 1945: Kritisk granskning av văra Macrolepidoptera dubiae [sic], en historisk-lepidopterologisk utredning. - Opusc. Entomol. 10: 65-97.

Bruun, H. 1977: Peribatodes secundaria ny för Finland. Not. Entomol. 57: 134-135.

Bruun, H. 1992: Changes in species composition of the moth and butterfly fauna on Houtskär in the Archipelago of SW Finland during the years on 1954-1989 (Lepidoptera: Hesperiidae-Noctuidae). - $\AA$ Abo Akademis förlag. $49 \mathrm{pp}$.

Clayhills, Th. H. 1957: Provinsen Nylandias Macrolepidoptera. - Fauna Fennica III: 1-83.

Dalman, J. V. 1816: Försök till systematisk uppställning af Sveriges fjärillar. — Vetensk. akad. handl. för år 1816.

Derzhavets, Yu. A., Ivanov, A. I., Mironov, V. G., Mishchenko, O. A., Prasolov, V. N. \& Sinev, S. Yu. 1986: Spisok cheshuekrylykh (Macrolepidoptera) Leningradskoy oblasti. - Trudy veesoyuznogo entomogicheskogo obshchestva 67: 186-270.

Fernelius, L.-E. 1981: Havaintoja perhoskannan muuntelusta Sipoon Linnanpellon kylässä. [Observationer över fjärilstammens variation i Sibbo Borgby.] - Baptria 6: 73-75. (In Finnish and Swedish.)

Fibiger, M. \& Svendsen, P. 1981: Danske natsommerfugle. —Dansk Faunistisk Bibliotek. Bind 1. Klampenborg. $272 \mathrm{pp}$.

Hanski, I. \& Woiwod, I. P. 1993: Spatial synchrony in the dynamics of moth and aphid populations. - J. Anim. Ecol. 62: 656-668.

Hanski, I., Kuussaari, M. \& Nieminen, M. 1994: Metapopulation structure and migration in the butterfly. Melitaea cinxia. - Ecology 75: 747-762.

Hanski, I., Pöyry, J., Pakkala, T. \& Kuussaari, M. 1995: Multiple equilibria in metapopulation dynamics. Nature 377: 618-621.

Heikinheimo, O. 1981: Suurperhoslajien runsauden vaihtelu Vantaan Tikkurilassa ja Janakkalassa 1970-luvulla valopyyntitulosten perusteella. [Frekvensvariationer av storfjärilsarter i Vanda Dickursby och Janakkala under 1970-talet baserat på ljusfångst.] — Baptria 6: 62-68. (In Finnish and Swedish.) 
Heikkilä, J., Below, A. \& Hanski, I. 1994: Synchronous dynamics of microtine rodent populations on islands in Lake Inari in northern Fennoscandia: evidence for regulation by mustelid predators. - Oikos 70: 245-252.

Heinicke, W. 1980: Zur Dynamik der Fauna der Noktuidae auf dem Gebiet der heutigen Deutschen Demokratischen Republik von 1862 bis 1978 (Lepidoptera). Acta Musei Reginaehradecensis Suppl. 193-197.

Hublin, Ch. \& Savolainen, E. 1985: Pohjois-Savon suurperhoset. - Kulumus 8: 1-86.

IPCC (Intergovernmental Panel on Climate Change) 1996: Climate change 1995 - The science of climate change. - University Press. Cambridge. 572 pp.

Järventausta, K., Avanto, A., Finneman, J, \& Haarto, A. 1988: Varsinais-Suomen suurperhosfauna 1870-1987. — Turku. $151 \mathrm{ss}$.

Julin, J. 1791-1792: Bref til Herr Intendenten Fischerström, om de uti Österbotten, särdeles omkring Uleåborg samlade naturalier. - Ny Journ. Hush.: 226-293 (1791), 3-34, 55-73, 105-137 (1792).

Julin, J. 1800: Förteckning på några uti Österbotten, särdeles omkring Uleåborg samlade naturalier med anmärkningar, - Ny Journ. Hush.: 101-123.

Kaisila, J. 1959: Die ältesten Angaben über die finnische Schmetterlingsfauna. - Ann. Entomol. Fenn. 25: 80102. (In Finnish with German summary.)

Kaisila, J. 1962: Immigration und Expansion der Lepidopteren in Finnland in den Jahren 1869-1960. - Acta Entomol. Fenn. 18: 1-452.

Kaisila, J. 1968: Changes in the Finnish macrolepidopteran fauna from 1946 to 1967. — Luonnon Tutkija 72: 97127. (In Finnish with English abstract.)

Kangas, J. K. 1994: Pälkäneen suurperhoset. — Diamina 1994a: 1-44.

Karvonen, J., Laasonen, E. M., Aalto, A., Kerppola, S. \& Karvonen, E, V. 1979: Lepidoptera species new to Finland, caught with continuous light trapping. -- Not. Entomol. 58: 153-158.

Kerppola, S. \& Mikkola, K. 1987: Autographa buraetica (Staudinger), a plusiine moth new to Finland and Europe (Lepidoptera, Noctuidae). - Not. Entomol. 67: 119-123.

Kononenko, V. S. \& Mikkola, K. 1992: Zoogeography of the autumn and spring fauna of the Noctuidae of the Palaearctic arboreal zone. - VIII European Congress of Lepidopterology (abstract). Helsinki.

Kontiokari, S. 1989: Etelä-Pohjanmaan suurperhoset. Not. Entomol. 69: 81-149.

Krogerus, H. 1989: Hur har de kalla åren inverkat på insekt-, särskilt fjärilsbestånden. - Mem. Soc. Fauna Flora Fennica 65: 73-76.

Krogerus, H. 1996: Chloroclystis v-ata relicta ssp. n. (Lepidoptera, Geometridae), a new taxon from SW Finland, doomed to go extinct? - Entomol. Fennica 7: 63-66.

Kullberg, J. 1997: Scopula decorata rediscovered in Finland. - Baptria 22: 84-86. (In Finnish with English abstract.)

Leinonen, R. 1993: Kainuun sururperhoset. - Baptria 18,
Suppl. 2a: ss. 1-73.

Lindström, J. 1994: Tetraonid population studies - state of the art. - Ann. Zool. Fennici 31: 347-364.

Linnaeus, C. 1739: Animalia per Sveciam observata. Acta lit. et scient. Svec. Anno 1736. Upsaliae.

Linnaeus, C. 1746, 1761: Fauna Svecica. - Stockholm.

Linnaeus (von Linné), C. 1758: Systema Naturae. Ed. X. - Stockholm.

Martikainen, R. \& Seuranen, I. 1988: Tampereen seudun suurperhoset. — Not. Entomol. 68: 61-93.

Marttila, O. 1991: Lepidoptera in Joutseno and Mäntyharju in 1990 and discussion about the population trends; in Finnish. - Baptria 16: 1-6. (In Finnish with English abstract.)

Marttila, O. \& Saarinen, K. (eds.) 1996: Perhostutkimus Suomessa. VII symposiumi 10.10.1996. —Etelä-Karjalan Allergia- ja Ympäristöinstituutti. Lappeenranta. $53 \mathrm{pp}$.

Marttila, O., Haahtela, T., Aarnio, H. \& Ojalainen, P. 1990: Suomen päiväperhoset. [Finnish butterflies.] — Kirjayhtymä. Helsinki. 362 pp. (In Finnish with English abstracts.)

Mikkola, K. 1966: Keräilyt Bromarvin Framnäsissä ja Tenholan Lindössä 1966. - Suomen Perhostutkijain Seura, kiertokirje 9/66: 2-3.

Mikkola, K. 1979: Vanishing and declining species of Finnish Lepidoptera. - Not. Entomol. 59: 1-9.

Mikkola, K. 1987: Changes in the Finnish lepidopteran fauna in relation to environmental changes. - Ent. Meddr. 55: 107-113. (In Swedish with English summary.)

Mikkola, K. 1997: Ilmasto lämpenee - etelän perhoset leviävät Suomeen. — Luonnon Tutkija 100(5): 157-168.

Mikkola, K. \& Salmensuu, P. 1965: Migration of Laphygma exigua (Lep., Noctuidae) in Northwestern Europe in 1964. - Ann. Zool. Fenn. 2: 124-139.

Nieminen, M. 1996: Metapopulation dynamics in moths. - University of Helsinki. Dissertation. 109 pp.

Parmesan, C. 1996: Climate and species range. - Nature 382: 765-766.

Pollard, E. 1991: Synchrony of population fluctuations: the dominant influence of widespread factors on local butterfly populations. - Oikos 60: 7-10.

Pollard, E., Van-Swaay, C. A. M. \& Yates, T. J. 1993: Changes in butterfly numbers in Britain and The Netherlands. - Ecol. Entomol. 18: 93-94.

Rassi, P., Alanen, A., Kemppainen, E., Vickholm, M. \& Väisänen, R. 1986. Suomen uhanalaiset eläimet. Komiteanmietintö 1985: 43. Helsinki.

Rassi, P., Kaipiainen, H., Mannerkoski, I. \& Ståhls, G. 1992: Uhanalaisten eläinten ja kasvien seurantatoimikunnan mietintö. - Komiteanmietintö 1991:30. Helsinki.

Rezbanyai-Reser, L. 1989: Ein Musterbeispiel der rezenten Arealerweiterung: Eupithecia sinuosaria Eversmann, 1848, bis zur Südostschweiz vorgedrungen (Lepidoptera, Geometridae). - Atalanta 19:39-50.

Sahlberg, C. R. 1819: Dissertatio Entomologica Insecta Fennica enumerans. - Turku.

Sevola, Y. (ed.) 1996: Statistical yearbook of forestry, - 
Metsäntutkimuslaitos. Jyväskylä. 352 pp. (In Finnish with English summary.)

Skou, P. 1991: Nordens ugler. - Apollo Books. Stenstrup. $566 \mathrm{pp}$.

Söderman, G., Lundsten, K.-E., Leinonen, R. \& Liukko, U.-M. 1995: Finnish moth monitoring newsletter 1994. — Tampere. 74 pp. (In Finnish, with English summary and figure captions.)

Sulcs, A. \& Viidalepp, J. 1972: Verbreitung der GrossSchmetterlinge im Baltikum. IV. Spanner. - Dtsch. Entomol. Z. N. F. 19: 151-209.

Sulcs, A., Viidalepp, J. \& Ivinskis, P. 1981: 1. Nachtrag zur Verbreitung der Gross-Schmetterlinge im Baltikum. Dtsch. Entomol. Z. N. F. 28: 123-146.

Suomalainen, E. 1987: Long-term changes in the Macrolepidoptera fauna of the Porvoo area on the southern coast of Finland. - Not. Entomol. 67: 165-174.

Sutcliffe, O. L., Thomas, Ch. D. \& Moss, D. 1996: Spatial synchrony and asynchrony in butterfly population dynamics. - J. Anim. Ecol. 6585-95.

Svensson, I. 1977: Förändringar i Sveriges storfjärilfauna en tredje tioårsperiod (Lepidoptera). - - Ent. Tidskr. 98 : 113-122.

Svensson, I. 1985: Influence of forestry on lepidopterous populations. - Proc. 3rd Congr. Eur. Lepid., Cam- bridge 1982: 166-167.

Tengström, J. M. J. af 1869: Catalogus Lepidopterorum Faunae Fennicae praecursorius. - Notiser ur Sällsk. pro Fauna et Flora Fennica förhandl. 7(n.s.): 287-370.

Urbahn, E. 1973: Beobachtungen über den Häufigkeitswechsel bei Schmetterlingen in Norddeutschland seit 1895. - Faunist. Abhandl. Staatl. Mus. f. Tierk. in Dresden 4: 45-60.

Urbahn, E. \& H. 1971: Häufigkeitsschwankungen bei Opigena polygona Schiff. (Lep., Noct.). — Entomol. Nachr. 15: $13-16$.

Valle, K. J. 1946: Mittarit, Geometrae. - Animalia Fennica 5. Macrolepidoptera IV. - Porvoo. 370 pp., 22 plates.

Varis, V., Ahola, M., Albrecht, A., Jalava, J., Kaila, L., Kerppola, S. \& Kullberg, J, 1995: Checklist of Finnish Lepidoptera. - Sahlbergia 2: 1-80.

Viidalepp, J. 1970: Veränderungen in der Makrolepidopteren-Fauna Estlands. - Eesti NSV Teaduste Akadeemia Toimetised 19: 53-77. (In Russian with German summary.)

von Bonsdorff, R. 1985: Lahden seudun suurperhosfauna. — Lahden museolautakunta, selvityksiä ja kannanottoja 25: 1-86, 5 liitettä.

Warnecke, G. 1961: Arealvergrösserungen bei Schmetterlingen. -- Bonner Zool. Beitr. 12: 113-141. 